Acta Univ. Sapientiae, Communicatio, 4, (2017) 7-35

DOI: 10.1515/auscom-2017-0001

\title{
Linguistic and Non-Linguistic Elements in Detecting (Hungarian) Fake News
}

\author{
Ágnes Veszelszki \\ Corvinus University of Budapest, Hungary \\ agnes.veszelszki@uni-corvinus.hu
}

\begin{abstract}
Fake news texts often show clear signs of the deceptive nature; still, they are shared by many users on Facebook. What could be the reason for this? The paper tries to answer the question by collecting the linguistic and non-linguistic characteristics of fake news. Linguistic characteristics include among others the exaggerating, sensational title, the eye-catching, tabloid-style text, the correct or incorrect use of terms, and the fake URLs imitating real websites; non-linguistic characteristics are expressive pictures often featuring celebrities, the use of all caps, excessive punctuation, and spelling mistakes. The corpus was compiled using snowball sampling: manipulative news not originating from big news portals were collected from the social networking website Facebook. The aim of the study is to identify the characteristics of Hungarian fake news in comparison to the English ones and to elaborate a system of aspects which help identify fake news.
\end{abstract}

Keywords: post-truth society, fake news, manipulation, social media, netlinguistics

\section{Introduction}

“HEADS UP! REALLY DANGEROUS TEA IS SOLD RIGHT OVER THE COUNTER! IT'S VERY POPULAR, YOU PROBABLY ALSO HAVE A PACKET IN THE KITCHEN BUT YOU SHOULD NEVER EVEN TRY IT! Throw it out or bring it back to the store immediately if you have bought one! It's the most popular tea on supermarket shelves! Here's the full heads-up message $>>>>>$ "

This is an article headline from a Hungarian website, an obvious example of clickbait. The exaggerations and the uppercase letters used in the text are (or should be) clear signs of the deceptive nature of the article; still, it was shared by many users on Facebook. What could be the reason for this? The paper tries to 
answer the question by collecting the linguistic and non-linguistic characteristics of fake news. The corpus was compiled using snowball sampling: manipulative news not originating from big news portals were collected from the social networking website Facebook. This time, political and lifestyle type news were not distinguished. This study ignored the potential fake news of otherwise trusted news portals and "alternative facts". However, concealed sites (i.e. sites containing news of better linguistic quality reached via non-suspicious links) can be problematic when selecting articles for the corpus. The aim of the study is, on the one hand, to identify the characteristics of Hungarian fake news and, on the other hand, to elaborate a system of aspects which help identify fake news.

\section{Fake News and Associated Concepts}

Back in 2002, well before the fake news problem reached its current level, James E. Katz and Ronald E. Rice wrote the following: "Sites [...] can propagate any rumour, assertion, or babble no matter how ludicrous, irrational, stupid, or hurtful. Any lie can be presented as truth. (On the other hand, people are allowed to post any truth or helpful comment as well [...])” (Katz-Rice, 2002: 311). These remarks have remained absolutely relevant even 15 years later, in 2017.

Online knowledge is not always reliable: the author, the sources, and the recency are often unknown, and the information is often uncontrolled, which means that anyone can publish anything. There can be misleading, pseudo-scientific, and sometimes outright harmful views on the Internet, which inadvertent readers can easily take for granted. The sources of knowledge have changed, and so Internet users have to develop a critical mind, a skill for the critical evaluation of information as part of their new media competence (Veszelszki, 2017a; 2017b). In fact, Andreas Schleicher, the Education Director of OECD (Organisation for Economic Co-operation and Development) goes even further, saying that "schools should teach young people about how to identify 'fake news"' (Coughlan, 2017). According to Schleicher, this kind of soft skill should be part of the global competencies and serves to counter the echo chamber/filter bubble effects.

Fake news are generally grouped into two categories based on the intentionality of their propagation: "fake news could be false information deliberately circulated by those who have scant regard for the truth but hope to advance particular (often extreme) political causes and make money out of online traffic. Or it could be false information circulated by journalists who don't realise it's false" (W2). It should be noted here that fake news are not (only and not primarily) propagated by journalists.

Fake news have more to do with the concepts of Internet frauds (phishing, spam, hoax, urban legends, and clickbait) and news parodies. In the following, I will briefly describe the two categories. 
According to Theresa Heyd (2013: 387), Internet frauds can be visual (such as neatly or badly manipulated, photoshopped images), but normally they are based on discourse, that is verbal communication. Such frauds can be analysed along two lines: whether their purpose is profit making or entertainment. Heyd (2013: 389390) classifies spam and phishing into the first group. Spam is unsolicited e-mail containing false or misleading information. Phishing, on the other hand, is the practice of fraudulently obtaining important data (passwords, login credentials) from users by simulating a trusted identity (such as an online banking interface). Both spam and phishing can have serious security and financial consequences.

The second group in Heyd's classification does not involve any financial risk, it rather has psychosocial implications: forwarding fake news is a sign of digital illiteracy and ignorance. Hoaxes belong to this category.

Hoax (with a financially deceptive purpose: scam) is purposely fabricated authentic-looking news with false or at least problematic information, which tends to go viral and is intended to have a humorous effect or to deceive others (Fenyvesi, 2016). "Hoaxes typically exploit users' naivety to dupe them into voluntarily forwarding and reposting them to their friends" (Fenyvesi, 2016: 445). So, hoax is the virtual form of gossip (Szvetelszky, 2002) and forms part of digital folklore (Balázs, 2015; Heyd, 2013; Veszelszki, 2011). Initially, online hoaxes were disseminated in e-mails, but now they are typically shared in social media (early examples of hoax: Aczél, 2017). "Classic e-mail virus hoaxes usually warn the recipients of non-existent security threats which will arrive via email" (Fenyvesi, 2016: 449). Prize hoaxes promise to reward all participants if the message reaches a specific number of users. Charity hoaxes and empathy hoaxes use one of the two main narratives, the "sick child" or the "lost child". Further types of hoax include fake advertisements, urban legends, pseudo-hoaxes imitating the style of fake news with the intent to have a humorous effect (Heyd, 2008), and pseudoscientific hoaxes putting the scientific world to the test (cf. the famous Sokal hoax: Sokal, 2008; Boghossian, 1996; Weinberg, 1996).

Hoaxes prototypically exploit people's goodwill and readiness to help. The persuasive strategies used to trick the recipients into forwarding the message including the following: providing help to small children or lovely animals (Three-month baby needs rare blood type), raising awareness of viruses (This new virus destroys your computer. Warn your friends, too!), reference to apparently credible sources (lawyer friend, large company), pseudo-scientific evidence, offering money ( $X Y$ pays you one dollar for each forwarded message.), threatening with bad luck (Send this to at least 8 people or face 8 years of bad luck in love.).

The way social networking websites display news and how users read them also contribute to the spread of hoaxes: on Facebook, the largest social networking website, ${ }^{1}$ information from other websites are displayed with the headline, a large

1 Facebook has more than 2 billion users in Q3 2017 (W8). 

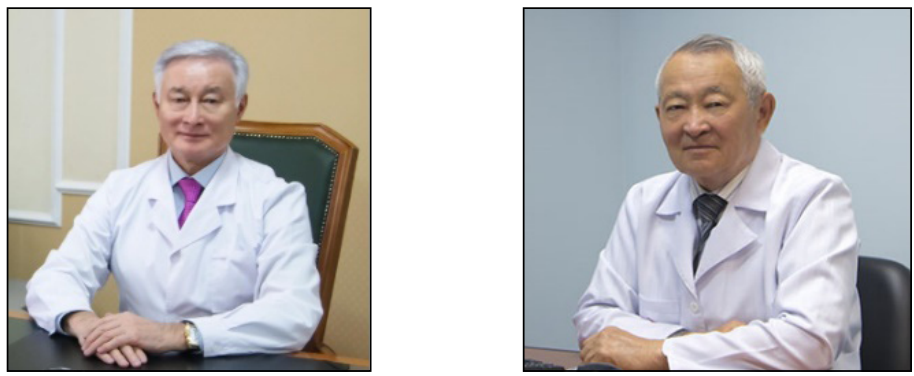

Images 1-2. The experts of the "Parasitology Institute"

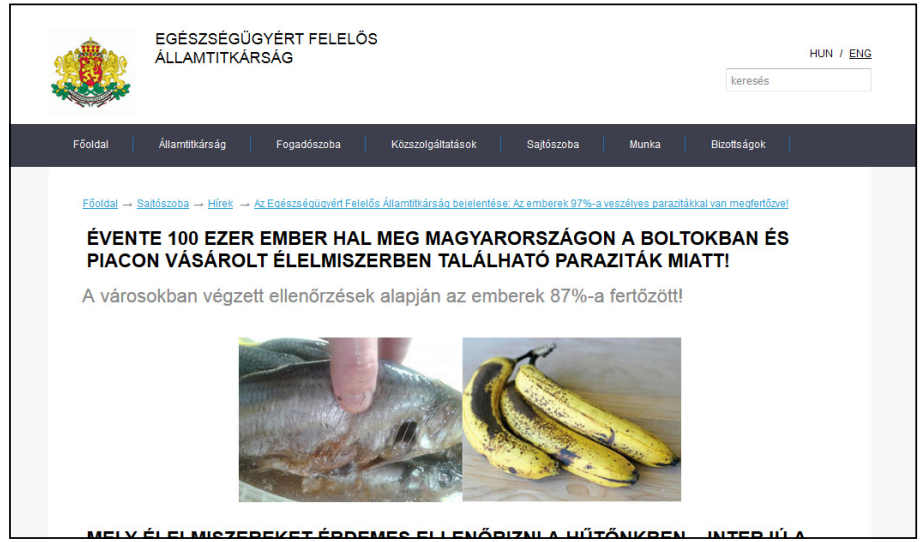

Image 3. The fake website of the State Secretariat

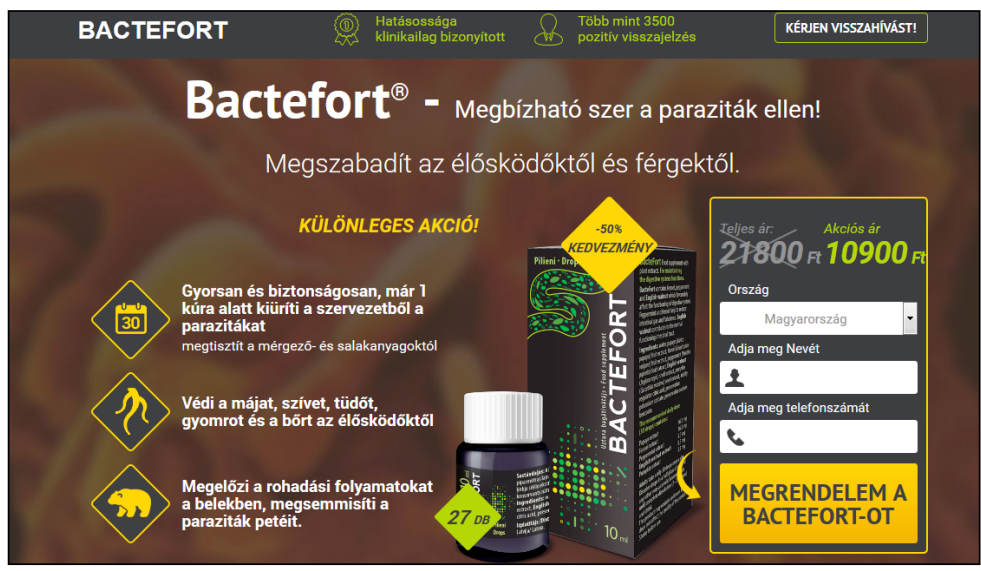

Image 4. Subpage content on the fake website 


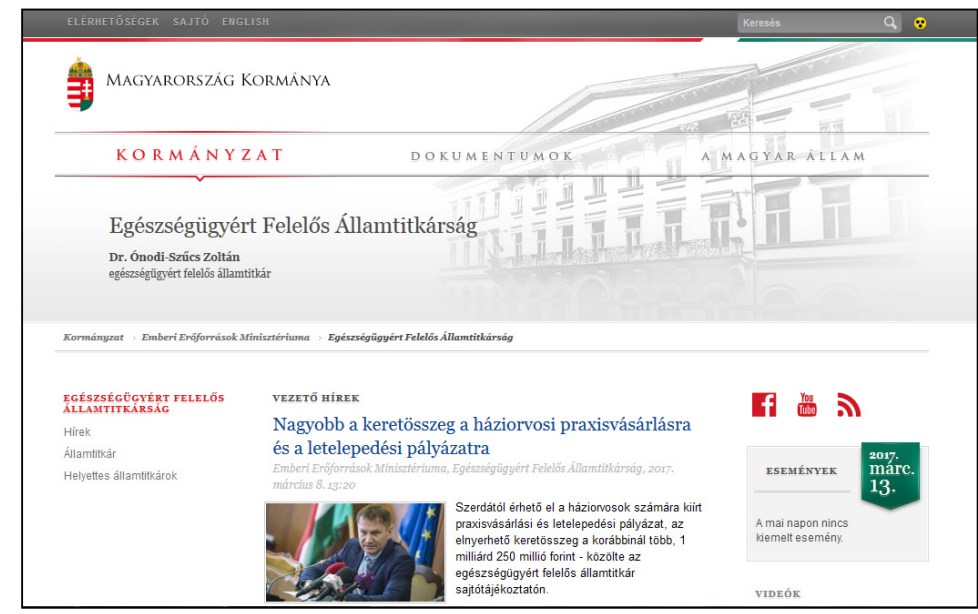

Image 5. The real website of the State Secretariat for Healthcare (15 March 2017)

picture, and perhaps the lead of the article. The typical headline is stunning, the picture egregious, and the lead mysterious. Many users do not even open the link (which may as well lead to a phishing or clickbait site) but send it on without thinking, thus spreading false information of fraudulent websites.

Urban legends represent a separate sub-type of fake news: they may have some element of truth to them, but all in all they are hoax-like stories, accounts and scare-news, like folklore (Veszelszki, 2011).

Fake news websites usually request users to click or share articles before reading them in order to view them, but sometimes the articles are not even displayed after the click/share (so their only purpose was to get the click/share, what they have achieved). If the article, picture, or video is displayed, while viewing, the user inadvertently shares spams on his or her Facebook page. The true intent behind such messages is usually to boost online advertising revenue by higher click-through rates. The goal of the so-called clickbait sites is to produce: "titles that manipulate or coerce readers into visiting the site” (W4).

Clickbait sites often fabricate pseudoscientific or politically misleading articles and publish them as real news; other times, they present news taken from other sites without permission. This kind of news presentation qualifies as manipulation for several reasons. Manipulation is a type of influence aimed at influencing others' ideas, opinions, emotions, and behaviour (Falyuna, in Veszelszki et al., 2017). Manipulation is related to persuasion but with the huge difference that the target person is usually not aware of being manipulated (Falyuna, 2016). Manipulative strategies also include making false allegations and statements (Árvay, 2007; Falyuna, 2016). According to Sissela Bok, lie belongs to the wider 
concept of deception; it is a deliberately misleading piece of information presented as a statement (Bok, 1983: 39).

By contrast, news parody, or satire is not necessarily deceptive or manipulative; the exaggerations used in them usually reveal their true nature (however, sometimes, Facebook users take ironic-satirical articles seriously and share them as real ones). Instead of deceit, news parodies rather intend to entertain others and caricature political or public events or figures. Their essence is to imitate the style, language, and news structure of news media. In Hungary, there is one website completely dedicated to satirical news (Hírcsárda) and even a frivolous political party, the Two-Tailed Dog Party, which uses the same mechanism (though it is increasingly concerned with real issues as well).

\section{Methodology: Corpus Analysis}

The corpus was compiled using snowball sampling: I collected the news shared by my friends on Facebook, checked their link against several lists of fake news websites, and if the linked site was listed, I copied the article into the corpus along with four other articles recommended on the same webpage. I always clicked on the first recommended headline without making any distinction between the texts. Using this method, $30+1$ texts were collected for examination. The corpus comprised nearly 9,500 words (more than 70,000 characters).

The additional one text may be particularly instructive: one of the recommended articles - compared to which the other texts look almost innocent - directed to a scaremongering and phishing website. The article discussed in detail the various forms of occurrence of parasites in an overly descriptive and naturally (?) deceptive manner illustrated with horrifying images. The storytelling copied the "problem followed by solution" model: the long-winded introduction (an interview with "Dr Adorján Kovács, Director of the Parasitology Institute" and "Prof. Dr Kálmán Fekete, Expert of the Parasitology Institute", with photos) ${ }^{2}$ was followed by the proposed medical treatment, more specifically, the presentation of a product called "Bactefort". The article claimed that the clinical tests supported by figures and photos were supervised by the State Secretariat for Healthcare. However, the link of the State Secretariat directed to a phishing page where all further links led to Bactefort advertisements. (The real website of the State Secretariat is inserted below for comparison.) This was the point where I stopped following and examining the links, as when I wanted to close one of the subpages, the computer told me in human voice: "Are you sure you want to close the page?" In fear of exposing my computer to viruses, I turned off my computer.

2 Due to the untraceability of online information, the interviewed people can be real professionals, outsiders, or fake professionals with real or fake academic titles (cf. Falyuna, 2017). 


\section{Findings}

\subsection{Linguistic Elements}

\subsubsection{Headlines}

The headline functions as an independent communication unit, but it also forms part of the text immediately following it. Thus, it has two main functions: the metatextual function, which relates to the text as a whole (it is a simple representation of the complex text and can even live a separate life), and its predictive function, which points at the content of the text (Tolcsvai Nagy, 2001: 325). As headlines play a key role in winning potential readers, they are discussed in detail below.

The headlines of the examined articles are without exception exaggerated, sensational, and eye-catching, or rather "click-catching". In each case, they had an explanatory character also marked by their length: the shortest one comprised five words and the longest one was 18 words long in Hungarian (1).

(1) His friends laughed at him for buying a hard drinker's apartment. But the result of the renovation left everyone speechless!

From a textological point of view, the headline deictically points at the text and metonymically represents it (Tolcsvai Nagy, 2001: 327). The deixis pointing outside the text and coreference used in the world of texts can make headlines enigmatic (2-3). This is also a tool to attract readers' attention and persuade them to open the article identified by the headline.

(2) This is what your fingerprints say about you!

(3) This is how young girls get robbed! Draw our children's attention to prevent tragedy!

Part of the headlines tries to shock, horrify, or scare the readers outright to trick them into clicking (4-5).

(4) BRUTAL surgical mistake! She went in to give birth but came out with no legs.

(5) Patient was declared dead but a few minutes later rose from the bed in Gyula Hospital. 
Headlines providing apparently important and allegedly official information (6-7) or raising awareness of health risks and food to avoid or giving advice (8-12) all aim to get the message shared and propagated.

(6) CHANGES IN PHARMACIES! DON'T EXPECT THE PRESCRIPTION >> HERE'S WHAT YOU'LL GET!

(7) Police announcement with photo! 2 migrants have escaped. They are very dangerous!; You may receive a package via registered mail. Don't even consider signing the return receipt and taking over the package!

(8) You drink it every day without suspecting that it can cause breast cancer!

(9) This is why Chinese garlic is dangerous! Better read this!

(10) It's more toxic than sugar or salt, still consumed by many on a daily basis!

(11) Attention! Warning! Really dangerous tea is sold right over the counter! It's very popular. If you also have a packet, you should never even try it!

(12) Dr Gábor Zacher's public announcement! Please, share so that everyone knows about this!

Headlines not only implicitly but also explicitly urge users to share the articles (13). Messages calling for help play on readers' benevolence (14).

(13) Tonight's full moon - share and soon your wish will come true.

(14) S.O.S. Balázs needs blood for a life-saving operation as $60 \%$ of his body was burned.

The mechanism of action behind story-starter and crime-story headlines (15), pseudoscientific news (16-19), and fake political news (20) is based on curiosity. Listicles are typical clickbaits (21-22).

(15) Troubling details: This was the last message of the missing Hungarian teenager. 
(16) 7,000-year-old corpse of a Hungarian girl was found by pipe workers in Szarvas.

(17) Neuroscientists created a song which can reduce anxiety by $65 \%$.

(18) Hidden picture found behind the Mona Lisa.

(19) 27 Latin American countries to introduce Transcendental Meditation.

(20) Transylvania to secede from Romania.

(21) These two-sentence horror stories will chill the blood in your veins.

(22) Common decorating mistake you should absolutely avoid!

Naturally, it is almost impossible to provide a comprehensive list of headline types, and there can be overlaps between them too (e.g. the article appealing to charity can also request sharing, 23).

(23) Boy who saved 15 students' lives now needs our HELP! SHARE!

This time, the corpus contained no headlines with the expression "breaking news", which is otherwise quite typical, but the intended impact is the same in the case of words like "attention” or "warning”, which did occur (24).

(24) Attention! Warning! Really dangerous tea is sold right over the counter! It's very popular; if you also have a packet, you should never even try it!

In certain cases, the headline is only loosely connected to the subsequent text. His friends laughed at him for buying a hard drinker's apartment. But the result of the renovation left everyone speechless! This headline is followed by an interior decorating "guide" with 17 random photos, which were definitely not taken of the same apartment. Not even elements of the eye-catching story in the headline (hard drinker, apartment purchase, friends' reaction) appear in the body text.

The headline usually aims to provoke emotions and thus increase the chance of tricking the (unsuspecting) users into sharing the content through social media (which generates profit for scammers). In relation to this, Brooke Binkowski, managing editor of the hoax-busting website Snopes, stated: "They are not just written to inform. I keep telling people if you read a headline and (after reading it) 
you're ticked off and you're angry and you're frustrated, then double check that source because you need to know whether or not it's legitimate” (Criss, 2017).

\subsubsection{Terms}

“Terms carry the special knowledge possessed by professionals but not (necessarily) by outsiders" (Falyuna, 2017). This is exactly why they have a convincing effect in the pseudoscientific discourse, where terms are usually "vague and undefined" or "taken from science but used in a different meaning" (Hargitai, 2012: 8).

In the following instance of fake news (25), the expressions in bold look like real terms (mostly foreign words in the Hungarian) and try to raise confidence in the text.

(25) 27 Latin American countries to introduce Transcendental Meditation (headline)

In the framework of an educational rehabilitation program, 27 Latin American countries are going to introduce the highly acclaimed knowledge-based educational programme, which includes Transcendental Meditation. Both students and teachers will practice TM in school time as part of the curriculum. (lead)

Father Gabriel Mejia, President of the Latin American Federation of Therapeutic Communities called on the leaders of all Latin American countries at the most recent congress. The foundation Fundación Hogares Claret led by the Columbian priest operates 54 social and educational centres in eight cities in Columbia. The centres give home to nearly 10,000 disadvantaged marginalized Columbian children - all of whom practice the Transcendental Meditation. In his call, Father Mejia referred to his 30-year-long experience.

The priest's proposal was enthusiastically welcomed, and several countries officially applied for the programme. Organized by Father Mejia, an independent coordination organization was established. Currently, they are organizing the railway transport of TM instructors. (body text)

\subsubsection{Style, Linguistic Quality}

The language of the texts can be news-like, imitating printed and online press (25). They are also characterized by the informal, almost personal style of tabloids including the use of T-form words (26-27).

(26) Kíváncsi vagy, milyen? Nem hiszed el, hogy működik? Hallgass bele! [Are you curious how it works? Unsure if it works at all? Just have 
a listen to it!] - where 'vagy', 'hiszed', and 'hallgass' are informal T-forms.

(27) Ha ezt iszod, fokozott a kockázat egy tanulmány szerint. [If you drink this, you are exposed to a high risk, study says.] - where 'iszod' is the T-form of the word 'inni' (to drink).

In the latter case, the lead does not follow Lasswell's traditional $5 \mathrm{~W}+1 \mathrm{H}$ formula but elaborates on the topic introduced in the headline (28-29). This solution functions as a hook to lure the reader into the text with the headlinelead-picture-URL combination when sharing the article in the social media.

(28) headline - This is what your fingerprints say about you! lead - Everyone has them, and they are unique (apart from identical twins); so, they are excellent for identifying your main personal characteristics.

(29) headline - This is why Chinese garlic is dangerous! Better read this! lead - Humanity has been passionately using this small vegetable comprised of cloves and having a distinctive taste for 6,000 years now. Garlic is so popular that every year one day, 19 April, is dedicated worldwide to it as the oldest plant used for seasoning.

A call to share in itself can give rise to suspicion. On two of the examined six pages, each and every article ended with a call to share, written in bold and capital letters (30-31).

(30) Please, share this to reach as many people as possible!

(31) PLEASE, SHARE THIS WITH OTHERS! THANK YOU! YOU CAN LEAVE A COMMENT BELOW.

The political texts in the corpus display open sarcasm or irony (32).

(32) Yesterday evening, the Momentum Movement basked in the glory of its success as it managed to submit another referendum question to Hungary's National Elections Office concerning the CEU. And guess what: I learned from the morning news that its dearest ally in the fight, the sleepy Democratic Party, was quicker this time and submitted the very same question at the very same place. 
The linguistic quality of the texts is well below the standard of written press, in terms of both style and spelling. There are a number of particularly remarkable typos in the texts (33).

(33) Óriási változás köszönt be a magyar gyógr gyógyszertárakban [Huge changes are about to come in Hungarian phamr pharmacies.]

The headline often says much about the linguistic quality (34). The "a Gyula a kórházban" structure may refer to both the Gyula Hospital and to the character. The relative pronoun aki [who] also fails to reflect the logic: a kórházban aki [in the hospital who].

(34) Halottnak nyilvánítottak egy beteget, a Gyula a kórházban aki percekkel később felkelt! [Literally: A patient was declared dead, but the Gyula in the hospital who a few minutes later rose from the bed.]

Spelling mistakes may also cause ambiguity or misunderstanding (35-36).

(35) Szókésben van 2 migráns! [2 migrants have escaped or 2 migrants are in the blondish] (szőkés [blondish] vs szökés [escape])

(36) Érdekesség a közéleti hölgyek sorrendjének elején sincs, hiszen azt Lévai Anikó [...] vezeti, szorosan a sarában Schmidt Máriával [There’s nothing unexpected in the list of the most influential Hungarian women (...) Anikó Lévai takes the lead followed by Mária Schmidt close on her heels] (sarában [in her mud] vs sarkában [on her heels]).

The overuse of punctuation marks and the use of all caps can also be suspicious (37-39).

(37) There's no protection from it, you can only prevent it. If you go to bars, nightclubs and parties, never leave your drink unattended and only accept unopened bottles! Unfortunately, sometimes it is slipped into seemingly intact bottles.... The festival season is on, so it is highly recommended to be very careful as you only have one life!!

(38) now please pay attention!!! Drum roll!

(39) DOCTORS FORGOT TO CHECK IT!!! (written in bold) 


\subsection{Non-Linguistic Signs}

\subsubsection{Content}

The shared materials can be classified into three main types: 1. pseudoscientific, 2. tabloid and call to action, and 3. political (fake) news.

The descriptive and also qualifying concept of pseudoscience relates to statements, teachings, theories, practices, and institutions which allegedly deal with science, but in reality their activity fails to comply with the basic requirements of science (cf. falsification, intersubjective controllability, reproducibility, and openness to criticism).

According to Sokal (2006), the critical spirit is one of the most important characteristics of science: "the commitment to the incessant testing of assertions through observations and/or experiments [...] and to revising or discarding those theories that fail the test" (Sokal, 2006: 288). By contrast, the advocates of pseudoscience reject every kind of criticism and "claim to be true in an objective sense" (Sokal, 2006: 289). They also consider themselves to be scientific and tie their statements to real scientific findings.

Further characteristic features of pseudoscience (illustrated with examples taken from the corpus):

1. Anachronistic thinking (making allegations that science has (long) refuted):

(40) To facilitate the Full Moon's energetic work, perform the following cleansing ritual [...] The easiest way to clean your apartment's aura and your aura is to burn sage. Walk around your home and in spirit request your environment to be cleansed energetically. Then follow the line of your body with the burner and request energetic cleansing for yourself as well. [...] The practice of letting go with Archangel Michael. Light a white candle. Pray to Archangel Michael as follows:

2. Searching for secrets (e.g. UFO, Bigfoot, spontaneous combustion);

(41) Based on health checks in urban areas, $87 \%$ of the population is infected! // Which type of food needs to be checked in the fridge? Interview with the Director of the Parasitology Institute! // Editor's note: the latest figures published by the World Health Organization (WHO) show that parasites in the human body are responsible for a large part of deadly diseases ranging from hepatitis and ulcer to cancerous tumours. Every year, 15 million people die because of 
the parasites. The infection is so widespread that they can be found practically in almost every person.

3. Reference to myths (the older the tale the more convincing it becomes);

(42) Certain legends hold that Leonardo hid a reference on Mona Lista [sic orig.] to the resting place of the Holy Grail or the holy artefact itself (as nobody has ever seen it, and there is no painting or photo of it). // Other sources say that "he who can see behind Monsa [sic orig.] Lisa" will discover the secret of eternal life. Anyhow, the discovery of the hidden picture only added to the guesswork in relation to the famous and enigmatic painting.

4. Biased handling of evidence (refers to evidence supporting its statement but ignores those contradicting it);

(43) Incredible! Hidden portrait found behind Mona Lisa, Leonardo da Vinci's famous painting, thanks to a special lighting method - BBC News Online reported on the stunning discovery of a French researcher. [...] The Louvre Museum did not comment on the announcement as it does not form part of the official research activities.

5. Irrefutable hypotheses (e.g. Creationism);

(44) In many cases in China, garlic farms are irrigated with unpurified waste water [...] // Gamma radiation is also applied to make the plants suitable for travelling several thousands of miles. These substances damage the garlic plants [...]. Instead, buy garlic produced in Hungary, it is much more worth it.

6. Seeming similarities (uses elements of proven and accepted theories in different meaning and context);

(45) Kaiser Permanente's research study proved that women who consumed full-fat products after having been diagnosed with breast cancer had died in higher numbers than those who switched to low-fat dairy products after the diagnosis.

7. Explanation with scenarios instead of facts; 
(46) Anxiety is one of the world's most terrible feelings. When suffering from anxiety, people are not in control of themselves and unable to fully master their body. // Many people sweat, their heart rate increases, they are short of breath, without any external cause. It has long been suspected that the solution must be in the head, in the mind. // In 1926, even Sigmund Freud discussed the phenomenon, but to date no effective solution has been found.

8. The allegation that facts are only interpretations;

(47) I personally have full trust in WHO statistics and I can say that our research at the Parasitology Institute confirms their figures. $92 \%$ of deaths are caused by parasitic infections. The presence of parasites in the human body are behind most "natural causes of death".

9. Immunity to criticism (as a basic pseudoscientific criterion) (Casti, 1990; cf. Pigliucci, 2010).

(48) The easiest way to clean your apartment's aura and your aura is to burn sage. Walk around your home and in spirit request your environment to be cleansed energetically. Then follow the line of your body with the burner and request energetic cleansing for yourself as well.

As examples (40) to (48) indicate, all these characteristics can be found in the examined allegedly scientific articles. The majority of the texts in the corpus belong to the pseudoscientific type (as categories overlap, there is no point in providing figures).

The second category of tabloids and calls to action includes messages with sensational elements, searching for missing people, asking for help, calling attention to dangers, and listicles.

1. Sensation:

(49) BRUTAL surgical mistake! She went in to give birth but came out with no legs!; Patient was declared dead but a few minutes later rose from the bed in Gyula Hospital. 
2. Missing persons:

(50) 15-year-old girl Marianna Dezső missing from Budapest. Last seen on 8 March! According to Together for Missing Children Foundation, ${ }^{3}$ she went home from her friend at Örs vezér tere. ${ }^{4}$ She last chatted with her mom on Facebook, saying she was very scared as there were many strange people on the tram. She never arrived home and is not responding to the messages any more...

3. Asking for help:

(51) S.O.S. Balázs needs blood for a life-saving operation, as $60 \%$ of his body was burned.

(52) Boy who saved 15 students' lives now needs our HELP! SHARE!

4. Awareness raising:

(53) This is how teenage girls are kidnapped for prostitution nowadays. If you get into this situation, it will probably be too late. Let's prevent tragedy by calling girls' and mothers' attention to this. Unfortunately, police can do nothing in $90 \%$ of the cases.

(54) Police announcement with photo! 2 migrants have escaped. They are really dangerous.

(55) Attention! Warning! Really dangerous tea is sold right over the counter! It's very popular; if you also have a packet, you should never even try it!

5. Listicles:

(56) A common decorating mistake you should absolutely avoid!

The third thematic category is politics. Originally, only relatively few political (fake) news were taken into the corpus. The reason for this is that the topic of the initial texts (esotericism, health, interior design, etc.) determined the topic of the recommended articles: the initial corpus of 25 texts only contained two

3 The link actually directs to the foundation's Facebook page: https://www.facebook.com/tear. kampany/?fref=ts.

4 Here the link leads to a Wikipedia page: https://hu.wikipedia.org/wiki/\%C3\%96rs_vez\%C3 $\%$ A9r_tere. 
(remotely) political articles. One deals with the migration crisis but in the form of police announcements (57).

(57) Police announcement with photo! 2 migrants have escaped. They are really dangerous.

The other one can only be considered political because of the political figure mentioned in its headline, but it conveys no actual political message: the political figure is Hungary's Prime Minister. The only content of the news is the following: Viktor Orbán is ill. The attached picture (machine gun soldiers guarding a building) and the headline is specifically sensationalist (58). The interrogative sentence makes the message less certain and less accountable. To make the article sound more authentic, its author put the words into the mouth of Bertalan Havasi, head of the Press Office of the Prime Minister but without providing any link or indicating any date, which greatly reduces the article's credibility.

(58) Tatabánya hospital is guarded by machine gun soldiers! Something really weird must be going on here! Is Viktor Orbán brought here?

Since, however, political themes prototypically play a key role in fake news, the first sample of 25 items was enriched through another sampling: starting from articles whose headlines mentioned the Hungarian Prime Minister (59), five additional texts were collected.

(59) Viktor Orbán's "hearth tax" - Friends coming for a barbecue and you want to light a fire? Pay 3,000 forints each time!

Each text is critical towards the Hungarian government (though it is not clear whether this criticism comes from the left or the right) with an expressly ironic or sarcastic tone (60).

(60) Once you have received the green light for your national grill party, you only have to memorize the legal regulations on lighting a fire, knowing that you can be fined 60,000 forints for even the smallest mistake.

Apart from the offensive, sarcastic tone, the texts in the political thematic corpus were characterized by the overuse of commonplaces (61).

(61) For the time being, it's still up in the air, you can't tell whether the new character will cause a great stir from the left or the right, but certainly it's only a matter of time. 


\subsubsection{Characters}

Political articles raise awareness by referring to well-known public figures (62). The name with the highest occurrence is Viktor Orbán, Hungary's Prime Minister, always coming at the front of the headline (63-65).

(62) The net is closing on Sebestyén Gorka, Trump’s far-rightist Hungarian adviser

(63) Orbán's "love affair" in Forbes! Who is the most influential woman in this country?

(64) Viktor Orbán’s hearth tax”...

(65) Orbánian outsourcing - bureaucracy reduction is only bullshit.

By contrast, the characters of non-political articles in the corpus (if any) are all unnamed everyday people (such as the 53-year-old Gyula, with the exception of the famous Hungarian toxicologist Gábor Zacher). In fact, in certain cases, it is even questionable whether the name and position indicated next to the picture in the text are real (66).

(66) Dr Adorján Kovács, Director of the Parasitology Institute. Clinical experience -46 years $^{5}$

\subsubsection{URL, Links, Traceability}

Fake news sites can be detected by having a look at their URL. Completely meaningless headlines are especially suspicious. Examples of more sophisticated names include sites promoting content consumption (e.g. ezt-figyeld.com, figyuzz. net, lajkolj.info), sites evaluating content (e.g. best-hir.com, csakneked.info, www. elkepeszto.net, erdekeshirek.info, exkluziv-videok.com, ezerdekes.eu, frenetikus. com), and sites whose names resemble that of real news or tabloid portals (e.g.

5 The topic is also covered by the Facebook page "Kamu termékek és szolgáltatások" [Fake products and services] (W6). One of the comments says: "Dr Attila Kállai, the bigwig of the non-existent National Parasitology Institute, who has published so many things. How unfortunate that a Swiss professor looks just like him." However, the efficiency of the fake news factory is clearly shown by the following comment allegedly written by a nurse (!), containing interesting linguistic characteristics. "These parasites do really exist in the human body and surely they can be cured, only nobody is interested in it. We rather spend the tremendous amount of money on drugs with no effect; I am convinced that this is effective!!! Just remember the time when Béres Drops appeared on the market!!! It was soon under fire by the whole medical world. I think today there are very few households without it. I was only at the beginning of my nursing career!" 
index.hu > index-blog.net; origo.hu > origo.blog.hu, hirorigo.net, origo-hirek. net, origoblog.net, origo-online.net; femcafe.hu > fm3cafe.hu; 24.hu > hir-24. info, hir27.in; hirstart.hu > hir-start.net, hir-start.com; hirado.hu > hirado-online. net, hirado.top). Website names focusing on knowledge can be suspicious (e.g. szabadonebredok.info, tudasfaja.com, ujvilagtudat.blogspot.hu). Banned websites almost immediately reappear in a slightly mutated form (e.g. mindenegybenblog. hu, mindenegyben-blog.com, mindenegybenblog.net, mindenegyben-blog.net, mindenegyhelyen.info, egyazegyben.com).

One means of online source criticism is to trace it back, that is check its origins. To enhance the deceptive effect, fake news sometimes contain links to sources, but these usually redirect to gossip sites (Propeller), tabloid sites (Blikk), or even official sites (Hungarian News Agency, Ministry, State Secretariat). These are only remotely related to the topic (cf. the message about the missing girl where a Wikipedia page was hyperlinked to the spot of disappearance, Örs vezér tere). Sometimes, fake news portals cross-refer to each other and build a network of reference to increase credibility (e.g. the site $A$ világ titkai refers to Tudnodkell. info or A tudás fája to ketkes.com as their source).

Besides the indication of the sources, the date and the author's name can also be informative when determining the credibility of the article (e.g. of fake announcements about missing people tend to circulate on the Internet for years). The major part of the examined texts completely failed to name the author, only the name of the site (e.g. Mindenegyben Blog, 24/7) or a nickname (e.g. dr rock) appears in the author field. In the political news, the same author's name appears three times, but clicking on it only reveals the articles written by the author and no other information. The impressum of Mindenegyben blog eloquently says nothing: The blog currently has two admins: a boy and a girl (W7).

\subsubsection{Pictures}

Apart from the esoteric articles of Mindenegyben blog, all articles contain at least one (but up to 18-20) picture. The text on parasites uses particularly many pictures about horrific parasites and fake physicians.

The following types can be identified based on the use of pictures and on the relationship between text and picture.

1. pictures are only remotely related to the text (Image 6),

2. illustration striking the keynote (Image 7),

3. picture underpins or completes the content of the text (Image 8),

4. picture about the person mentioned in the text (Image 9), and

5. text written for the photo collection (Image 10). 


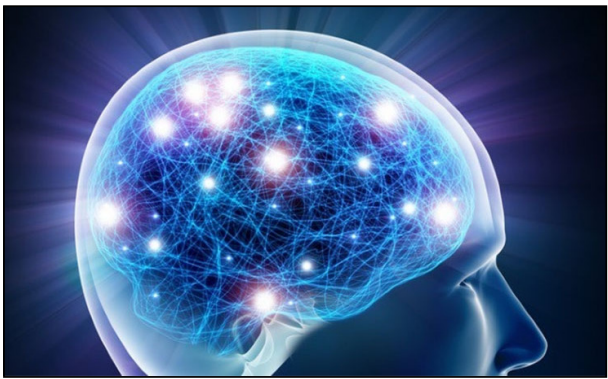

Image 6. Illustration for the article on neuroscience

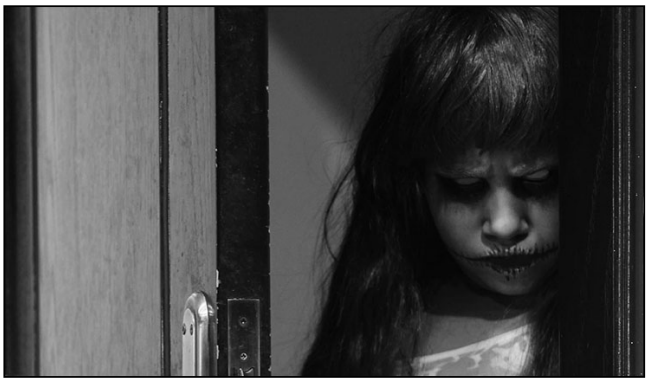

Image 7. Illustration for the article on horror stories

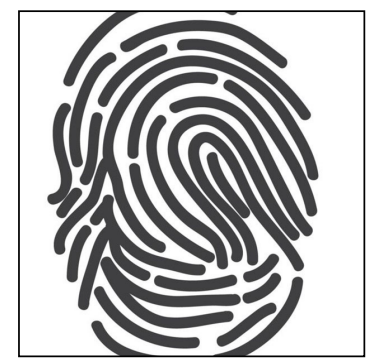

Image 8. Illustration for the article on fingerprint patterns

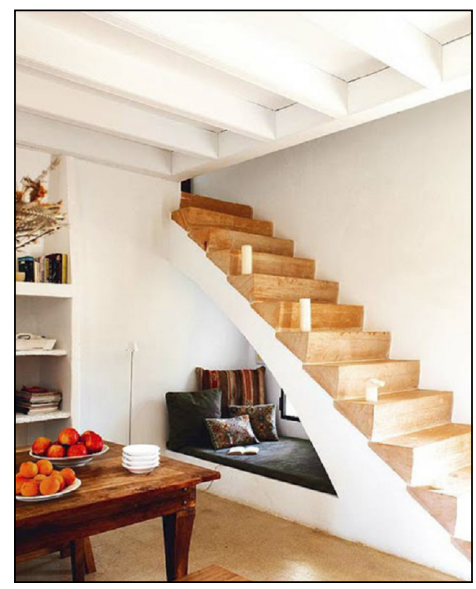

Image 10. Illustration for the article on interior design (the article features 17 pictures with a one-sentence comment to each)

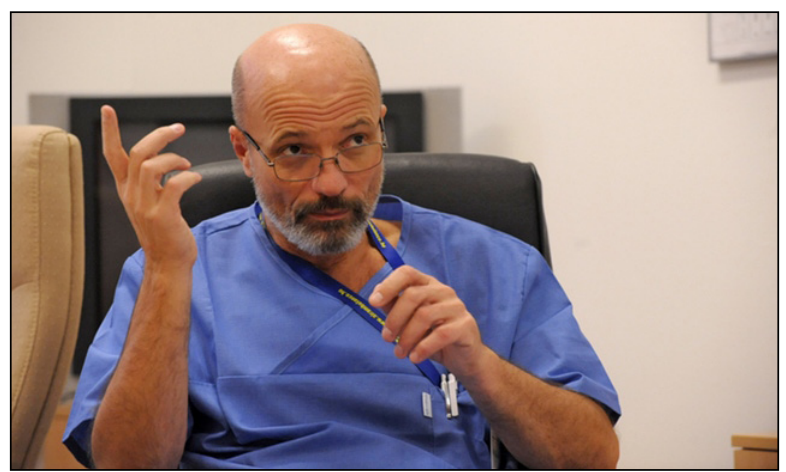

Image 9. Illustration for the article on drugs, Gábor Zacher toxicologist 
Picture, text, and lead are displayed on Facebook as follows:

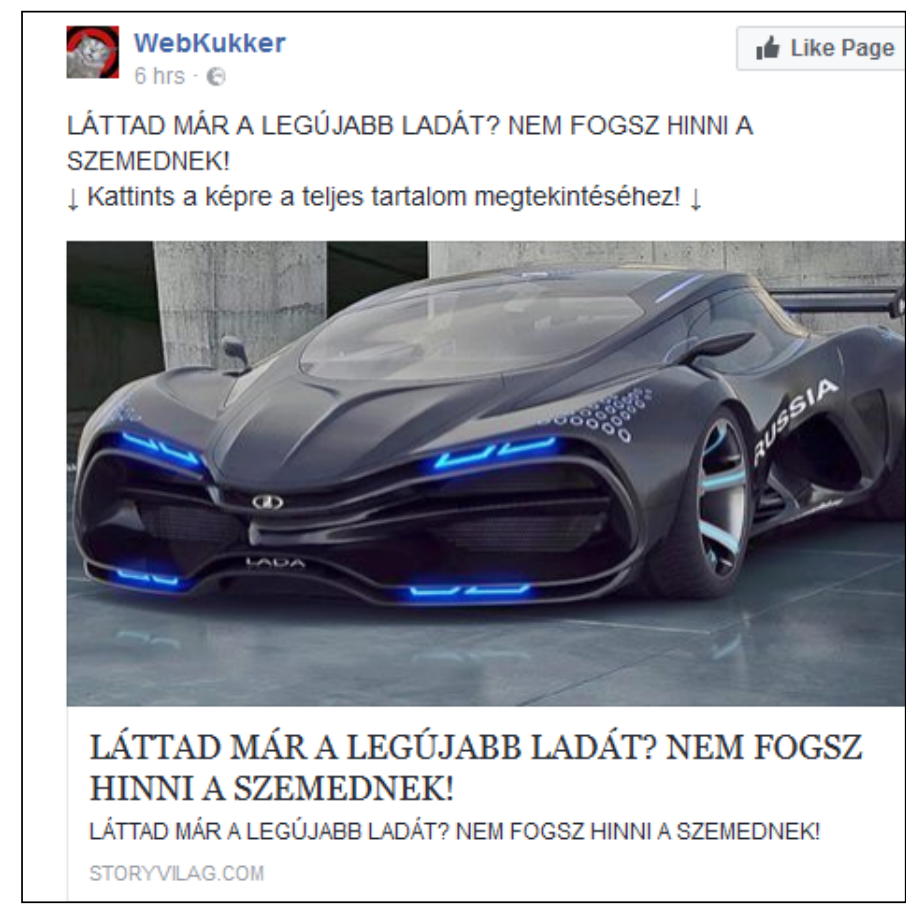

Image 11. Display of news on Facebook

\section{Summary}

The present study aimed to present the linguistic and non-linguistic characteristics of Hungarian fake news through a smaller sample and to create a comprehensive system of criteria for the recognition of fake news. Online guides provide help to spot fake news primarily for young inexperienced users who are considered particularly vulnerable in this respect. However, instead of young users who are increasingly conscious in consuming media content, the focus should be shifted to older generations, who also use the Internet, more specifically Facebook, on a daily basis ${ }^{6}$ (Veszelszki, 2016).

In response to the mounting criticism, Facebook has given top priority to the fight against fake news. "Over the past month, Facebook has begun rolling out a [...] new addition to the site: a bright red warning label that identifies fake news

6 The news portal Index.hu published a very accurate article on the vulnerability of older people using Facebook alone, which might as well have been published as a sociological study involving participant observation (W5). 
stories as 'disputed' and asks you to think twice before sharing them" (Romano, 2017). There are also more and more guides dealing with fake news. Summing them up and completing them with the results of this study, I compiled the following list to help detect fake news:

1. Look closely at the URL.

2. Is the source reliable?

3. Be sceptical of headlines. (Too detailed sensationalist headlines must be handled critically.)

4. Watch for unusual formatting.

5. Check the photos. (If the images are not clearly authentic, such as in the case of missing persons, Google Image Search service can be useful.)

6. Check the author.

7. Check the date.

8. Check the evidence.

9. Look at other reports.

10. Overcome your prejudice.

11. Check the linguistic quality and stylistic characteristics of the text.

12. Is it not a joke? (Joke sites can be misleading.)

13. Some stories are intentionally false.

14. Ask the experts.

It only takes basic IT skills to create a news-portal-looking (blog) site, though very amateurish attempts are easy to spot. More sophisticated, more concealed websites, however, pose a real problem as they publish articles with better linguistic quality under apparently trustworthy links, providing references, date, and author.

Nevertheless, there is further research potential in comparing Hungarian fake news with other misleading texts written in other languages, designed for different audiences. It could also be a promising research direction to explore who are interested in maintaining fake news sites apart from entrepreneurs expecting profit from like-hunting.

\section{References}

Aczél, P. (2017). Az álhír. Kommentár a jelenség értelmezéséhez. Századvég 84: 5-25. Árvay, A. (2007). The Analysis of Manipulation in Hungarian and American Written Advertising Discourse. Doctoral dissertation. Manuscript. Budapest: Eötvös Loránd University.

Balázs, G. (2015). Netfolklór - intermedialitás és terjedés. Replika 90-91: 171-185. Boghossian, P. (1996). What the Sokal Hoax Ought to Teach Us. Times Literary Supplement 14-15. 
Bok, S. (1983). A hazugság. A köz- és magánélet válaszútjai. Budapest: Gondolat Kiadó.

Casti, J. L. (1990). Verlust der Wahrheit. Streitfragen der Naturwissenschaften. Munich: Droemer/Knaur.

Coughlan, S. (2017). Schools Should Teach Pupils How to Spot 'Fake News'. $B B C, 18$ March 2017. http://www.bbc.com/news/education-39272841 [06. 04. 2017].

Criss, D. (2017). Where Fake News Goes to Die. How Snopes Battles Bigfoot Rumors, Facebook Fibs and Other Made-Up News. CNN, 10 March 2017 [06. 04. 2017].

Falyuna, N. (2016). Az arcvédő hazugság: A szívességkérés elutasításában megjelenő hazugság vizsgálata. Jelentés és Nyelvhasználat 3: 21-48.

Falyuna, N. (2017). Az áltudományos szövegek pragmatikai vizsgálata. Esettanulmány a lúgosító diéta példáján. Századvég 84: 85-107.

Fenyvesi, J. (2016). Az álhírek innovációja az idő és a technológia változásával. In: Balázs, G.-Veszelszki, Á. (eds), Generációk nyelve. Tanulmánykötet. Budapest: Mai Magyar Nyelvi Tanszék-Inter-Magyar Szemiotikai Társaság, 445-452.

Hargitai, Zs. Á. (2012). Áltudományos állítások és módszerek kémiai és biológiai elemzése. MA thesis. Manuscript. Budapest: Eötvös Loránd University, Institute of Chemistry.

Heyd, T. (2008). E-Mail-Hoaxes. Form, Function, Genre Ecology. Amsterdam: John Benjamins Publishing Company.

(2013). Email Hoaxes. In: Herring, C. S.-Stein, D.-Virtanen, T. (eds), Pragmatics of Computer-Mediated Communication. Berlin: De Gruyter, 387-409.

Katz, J. E.-Rice, R. E. (2002). Social Consequences of Internet Use: Access, Involvement, and Interaction. Cambridge, MA - London: MIT Press.

Pigliucci, M. (2010). Nonsense on Stilts. How to Tell Science from Bunk. Chicago: University of Chicago Press.

Romano, A. (2017). Facebook is Fighting Fake News by Making It Harder-or at Least More Annoying-to Share. Vox, 24 March 2017. http:/www.vox.com/ culture/2017/3/24/15020806/facebook-fake-news-alert-fact-checking [06. 04. 2017].

Sokal, A. D. (2006). Pseudoscience and Postmodernism: Antagonists or FellowTravellers? In: Fagan, G. G. (ed.), Archaeological Fantasies: How Pseudoarchaeology Misrepresents the Past and Misleads the Public. London: Routledge, 286-361. (2008). Beyond the Hoax. Science, Philosophy and Culture. Oxford: Oxford University Press.

Szvetelszky, Zs. (2002). A pletyka. Budapest: Books in Print.

Titcomb, J. (2017). Facebook to Educate Users about Fake News. Telegraph, 6 April 2017. http://www.telegraph.co.uk/technology/2017/04/06/facebook-educate-usersfake-news/ [06. 04. 2017]. 
Tolcsvai Nagy, G. (2001). A magyar nyelv szövegtana. Budapest: Nemzeti Tankönyvkiadó.

Veszelszki, Á. (2011). Lájkolom! A Facebook-folklórról. In: Csiszár, G.-Darvas, A. (eds), Klárisok. Tanulmánykötet Korompay Klára tiszteletére. Budapest: ELTE, Magyar Nyelvtörténeti, Szociolingvisztikai, Dialektológiai Tanszék, 379-390. (2016). Intergenerációs különbségek a digitális kommunikációban. Esettanulmány 65 év feletti nyelvhasználókkal. In: Balázs, G.-Veszelszki, Á. (eds), Generációk nyelve. Tanulmánykötet. Budapest: Mai Magyar Nyelvi Tanszék-Inter-Magyar Szemiotikai Társaság, 233-248.

(2017a). Netnyelvészet. Bevezetés az internet nyelvhasználatába. Budapest: L’Harmattan Kiadó.

(2017b). Digilect. The Impact of Infommunication Technology on Language. Munich: DeGruyter.

(2017c). Az álhírek extra- és intralingvális jellemzői. Századvég 84: 51-82.

Veszelszki, Á.-Falyuna, N.-Fodorné Tóth,K.-Tóth, A. (2017). AzInternetbiztonság kommunikáció- és nyelvtudományi aspektusból. Manuscript.

Weinberg, S. (1996). Sokal's Hoax. New York Review of Books 43(13): 11-15.

\section{Online Sources}

W1 = Kamu eltúnések, kamu betegségek - weboldalak, melyeket büntetni kéne! Családinet, 13. 03. 2015. http://www.csaladinet.hu/m/hirek/szabadido/hirek erdekessegek/21516/kamu_eltunesek_kamu_betegsegek_-_weboldalak_ melyeket_buntetni_kene [06. 04. 2017].

W2 = n.d. 2017: World Wide Web Creator Tim Berners-Lee Targets Fake News. BBC, 12 March 2017. http://www.bbc.com/news/technology-39246810 [06. 04. 2017]. W3 = Itt a nagy átverős lista: weboldalak, melyeknek soha ne higgyen el semmit.

HVG.hu, 2015. január 19., 2017. március 06. http://hvg.hu/tudomany/20150119_ atveros_weboldalak [06. 04. 2017].

W4 = Roberts, Michael Reid: Life Sentences: The Grammar of Clickbait! The American Reader. http://theamericanreader.com/life-sentences-the-grammar-ofclickbait/ [06. 04. 2017].

W5 = Hanula, Zsolt 2015: Nem a gyerekeket kell félteni az internettól, hanem a nyugdíjasokat. Index.hu, 2015. 09. 10. http://index.hu/tech/2015/09/10/nem_a_ gyerekeket_kell_felteni_az_internettol_hanem_a_nyugdijasokat/ [06. 04. 2017].

$\mathrm{W} 6=\mathrm{https}: / / \mathrm{m}$.facebook.com $/$ kamutermekek/posts $/ 480303099025874$ [06. 04 . 2017].

$\mathrm{W} 7$ = http://www.mindenegybenblog.hu/ [06. 04. 2017].

W8 = https://newsroom.fb.com/news/2017/06/two-billion-people-coming-togetheron-facebook/ [27. 06. 2017]. 


\section{Annex}

Annex 1: Black list (source: W1, W3)

- 2perc - 2perc.info

- Ajánlom magamat - ajanlom-magamat.com

- Aktív Blog - aktiv-blog.com

- Aktív Hírek - aktiv-hirek.net

- Bakkecske.NET - facebook.com/bakkecske.net

- Best hír - best-hir.com

- Bizony - bizony.eu

- Boroskóla - boroskola.info

- CikkElek - cikkelek.eu

- Csak neked - csakneked.info

- Csúcshatás - csucshatas.eu, szupcsi.eu

- Csumida - csumida.com

- Dinamikus - dinamikus.com

- Egészséges pont - egeszsegespont.hu

- Egy az Egyben - egyazegyben.com

- Éljünk szabadon - eljunkszabadon.co.vu

- Elképesztő - www.elkepeszto.net

- Érdekes hírek - erdekeshirek.info

- Exkluzív Videók - exkluziv-videok.com

- Extrém blog - extremblog.com

- Ez érdekes - ezerdekes.eu

- Ez nem piti - eznempiti.eu

- Ez zsír - ez-zsir.net

- Ezt figyeld - ezt-figyeld.com / ezt-figyeld-blog.com

- Ezt nézd meg - eztnezdmeg.info / eztnezdmeg-blog.com

- Face Nemzedék - face-nemzedek.com

- Figyuzz - figyuzz.net

- Filmhír / Mókamiki - filmhir.net

- First Videó - first-video.net

- FM3 Café - fm3cafe.hu

- Fogjunk össze - fogjunkossze.com

- Frankó - franko.info

- Frenetikus - frenetikus.com

- Friss világ - frissvilag.com

- Globire - globire.info

- Gonosz majom - gonosz-majom.com

- Hétperc - www.hetperc.com

- Hír 24 blog - hir-24.info 
- Hír 27 - hir27.in

- Hír Online - hir-online.com / hironline24.net

- Hír Start - hir-start.net, hir-start.com (not: hirstart.hu)

- Híradó Online - hirado-online.net

- Híradó.top - hirado.top

- Hírek online - hirek-online.com

- Hírek.TOP - hirek.top

- Hírexpressz - hirexpressz.top

- Hírjárat - hirjarat.com

- Hírkalap - hirkalap.net

- Hírkert - hirkert.info

- Hírközlő - hirkozlo.com

- Hírlexikon - hirlexikon.eu

- Hírmadár - hirmadar.com

- Hírnap - www.hirnap.info

- Hírorigo - hirorigo.net

- Hírportál - hirportal.info

- Hírszabadság - hirszabadsag.blogspot.com

- Hírtop - hirtop.in

- Hírtrafik - hirtrafik.top

- Hírvilág - hirvilag.co

- HúsosPizza - husospizza.com

- Index Blog - index-blog.net

- Képzavar - kepzavar.info

- Királyvidi - kiralyvidi.eu

- Kiskegyed(-utánzat) - kiskegyed.creatorword.com

- Kukucs - kukucs.info

- KutyaPisti - kutyapisti.eu

- Lájkolj - lajkolj.info

- Lapzárta - lapzarta.com

- Láttadmár? - lattadmar.eu

- Legfrissebb - legfrissebb.info

- Legjava - legjava.com

- Macskajaj - macskajaj.net

- Mai Friss - mai-friss.com

- Mai Hírek - mai-hirek.net

- Médiavadász - mediavadasz.info

- Megdöbbensz - megdobbensz.info

- Meglepő - meglepo.info

- Meglesem / Hot Pixel - hotpixel.co.vu

- Megoszthatod - megoszthato.blogspot.hu 
- Meteon - meteon.org

- Minden egy helyen - mindenegyhelyen.info

- Mindenegybenblog-mindenegybenblog.hu/mindenegyben-blog.com/minden egybenblog.net / mindenegyben-blog.net

- Mókavilág - mokavilag.com

- Mókuskerék - mokuskerek.club

- Mulató - mulato.info

- Nagy alku - a-nagy-alku.com

- Nagyonjoo - nagyonjoo.com

- Napi Friss - napi-friss.com

- Napi Hír - napi-hir.net

- Napi Hírek - napi-hirek.net

- Napi humor - napi-humor.hu

- Napi Média - napi-media.com

- Napi Migráns - napimigrans.com

- Napi Trend - napitrend.blogspot.hu

- NaturaHírek - naturahirek.com

- NetBetyár Blog - netbetyar.me

- Netextra/Érdekes világ - netextra.hu, erdekesvilag.eu

- NetHír - nethir.eu

- Nyaralok.net - nyaralok.net

- Organikusok - organikusok.blogspot.hu

- Origo Blog - origo-blog.com

- Origo Hírek - origo-hirek.net / origoblog.net

- Origo Online - origo-online.net

- Pályázatfigyelő - palyazatfigyelo.info

- Pletyka - pletyka.eu

- Plusz Café - pluszcafe.hu

- Pöpec - popec.net

- Segíthetek - szupertanacsok.blog.hu

- Skubizd - skubizd.info

- Szabadon Ébredők - szabadonebredok.info

- Tények 24 - tenyek24.net

- Tények Online - tenyek-online.com

- Top Hírek - tophirek.hu

- Tricikli - tricikli.com

- Tudás Fája - tudasfaja.com

- Tudnodkell - tudnodkel.blogspot.com / tudnodkell.info

- Új Világtudat - ujvilagtudat.blogspot.hu

- Vakarék - vakarek.info

- Vattacukor - vattacukor.net 
- Vicces-humoros - vicces-humoros.com

- Vidámság - vidamsag.postr.hu

- Videó Bázis - video-bazis.com

- Video Line - vidnline.com

- Videó Perc - www.video-perc.net

- VideoJohny - videojohny.eu

- VideoPista - videopista.eu

- Világ helyzete - vilaghelyzete.blogspot.com

- Világpolgár - vilagpolgarok.blogspot.hu

-xCore Blog - www.xcore.in

\section{Annex 2: Article headlines}

1. Ma esti telihold - oszd meg és hamarosan teljesül a kívánságod.

2. VÁLTOZÁS A GYÓGYSZERTÁRAKBAN! NE VÁRJA A RECEPTET >>> MUTATJUK MIT FOG KAPNI HELYETTE!

3. Aggasztó részletek: Ez volt az eltúnt magyar tini utolsó üzenete.

4. Hétezer éves magyar lány sírjára bukkantak vezetékcsere közben Szarvason.

5. S.O.S Vérre van szüksége az életmentő mútéthez Balázsnak, ugyanis teste $60 \%$-a megégett.

6. Idegkutatók létrehoztak egy olyan dalt, ami 65\%-kal képes csökkenteni a szorongást!

7. Ezektől a kétmondatos rémtörténetektől még az ereidben is meghúl majd a vér.

8. Minden nap isszuk, de nem sejtjük, hogy mellrákot okozhat!

9. Ezt árulja el rólad az ujjlenyomatod!

10. Rejtett kép rejtőzik a Mona Lisa mögött.

11. Ezért veszélyes a kínai fokhagyma! Erről jobb, ha tudsz!

12. Mérgezőbb, mint a cukor vagy a só, sokan mégis naponta fogyasztják!

13. 27 latin-amerikai ország vezeti be a Transzcendentális Meditációt.

14. Gyakori lakberendezési hiba, amit semmiképp se kövess el!

15. A barátai csak nevettek rajta, hogy egy alkoholista lakását vette meg. A lakásfelújítás eredménye azonban mindenkit lenyúgözött!

16. 15 diák életét mentette meg a fiú, aki most a SEGÍTSÉGÜNKET kéri! OSSZÁTOK!

17. Dr. Zacher Gábor felhívja a lakosság figyelmét! Kérlek osszátok, hogy mindenki tudjon róla!

18. Így rabolják el a fiatal lányokat! Hívjuk fel gyermekeink figyelmét és előzzük meg a tragédiát!

19. Rendőrségi felhívás fotóval! Szőkésben van 2 migráns! Nagyon veszélyesek!

20. BRUTÁLIS orvosi múhiba! Szülni ment be a nő és láb nélkül ébredt! 
21. Halottnak nyilvánítottak egy beteget, a Gyula a kórházban aki percekkel később felkelt!

22. Gépfegyveres katonákkal őrzik a Tatabányai kórházat!Nagy lehet a baj!Orbán Viktort ide hordják?

23. Névre szóló csomagot kaphat! Semmiképpen ne írja alá az átvételi elismervényt és ne vegye át a csomagot!

24. Erdély el fog szakadni Romániától.

25. Figyelem! Vigyázat! Nagyon veszélyes sót hoztak forgalomba! Nagyon népszerú, ha önnél is van belőle semmiképpen ne sózzon belőle!

26. Orbán Viktor “füstadója” - ha tüzet akar gyújtani a saját portáján, mert jönnek a barátok szalonnát sütni? Fizessen minden egyes alkalommal 3000 forintot!

27. Újabb csatamező - Semmiből jött pártkezdemények attakja, és hol van még 2018.

28. Szorul a hurok Gorka Sebestyén, Trump szélsőjobbos magyar tanácsadója nyaka körül.

29. Orbán „nő-ügye” a Forbesban! Ki a legbefolyásosabb asszony e hazában?

30. Orbáni kiszervezés - avagy a bürokráciacsökkentés csak duma.

+ 1 Évente 100 ezer ember hal meg Magyarországon a boltokban és piacon vásárolt élelmiszerben található paraziták miatt! 